\title{
Preventing Brain Drain: Kazakhstan's Presidential "Bolashak" Scholarship and Government Regulations of Intellectual Migration
}

\author{
Baurzhan Bokayev, PhD \\ Academy of Public Administration under the President of the Republic of Kazakhstan, \\ 33 a Abay Avenue, Office 501, Nur-Sultan, Kazakhstan \\ Zulfiya Torebekova \\ Syracuse University, USA \\ 2017 East Genesee Street, Apt. 2, Syracuse, NY, USA 13210 \\ Zhuldyz Davletbayeva, PhD \\ Academy of Public Administration under the President of the Republic of Kazakhstan, \\ 33 a Abay Avenue, Office 501, Nur-Sultan, Kazakhstan \\ cross $^{r e f} \underline{\text { http://dx.doi.org/10.5755/j01.ppaa.19.3.27764 }}$
}

\begin{abstract}
This article considers the Republic of Kazakhstan's internal intellectual migration within the scope of the Bolashak International Scholarship Program which aims to train highly-killed specialists at the best universities in the world. The analysis covers mechanisms of public investment in training of highly-qualified specialists, regulatory measures to promote employment opportunities nationally and the geographical scope of internal-intellectual migration of Bolashak graduates. A survey of Bolashak graduates assesses the country's labour market capacity and detects factors affecting migration among Kazakh youth.

The study showed that most graduates of the Bolashak program want to contribute to the development of the country, but they are not satisfied with the level of wages in Kazakhstan. Migratory moods were noted only among graduates aged 23-28 years, while older graduates aged 29 to 35 still preferred to stay at home. Moreover, among the first group of graduates, the priority was given to the standard of living in the country of destination rather than professional opportunities. Graduates from the second group were more interested in career prospects rather than in the standard of living in the country of destination.

This research was funded by the Science Committee of the Ministry of Education and Science of the Republic of Kazakhstan (Grant No. AP05136246).
\end{abstract}

Keywords: intellectual capacity, Bolashak program, cultural settings, stereotypes, migration, brain drain.

Raktažodžiai: intelektinis pajègumas, programa „,Bolashak“, kultūrinè aplinka, stereotipai, migracija, protu nutekejimas.

\section{Introduction}

The presidential Bolashak scholarship program is the most prestigious international educational program in Kazakhstan that enables highly competitive students to study at top global universities. The word bolashak means "future" in Kazakh. Most of over ten thousand graduates of the program currently work in the country's major cities, Nur-Sultan and Almaty. However, in order 
to better distribute the benefits of their investment, the Kazakh Government promotes working opportunities at the regional level aimed at eventually balancing the number of Bolashak alumni across the country.

Previous studies have assessed the effectiveness of the Bolashak program mainly by estimating the scope of innovative projects initiated by the program's alumni. This study will contribute to the existing literature by providing an analysis of government measures to regulate the flow of highly-skilled workers and thereby assist in fostering socio-economic development in the country.

This study is written in a context of an overall outflow of Kazakhstani talents to more advanced countries, a problem common in the developing world. Over the past four years, the recorded migration of highly-qualified specialists consisted of a particularly large number of representatives of STEM specialties, doctors and teachers leaving the country, due to inadequate compensation. In 2019 alone, this included over 4.8 thousand engineers, 2.7 thousand economists, and 1.7 thousand pedagogical specialists. Meanwhile, the numbers of potential employees who entered Kazakhstan in the same year among technical, economic and pedagogical fields were only 990, 627, and 537 respectively (Committee of Statistics 2019).

The rules of the program clearly state that Bolashak alumni must return to Kazakhstan upon completing their studies abroad to perform compulsory labour activities for 3 - 5 years. However, many of those who return desire to eventually leave the country for permanent residence abroad after completing their work obligation, while some Bolashak scholarship holders decide not to return at all.

In this regard, this article analyses the migratory mood among Bolashak graduates. Seven hundred forty-two Bolashak graduates and current students participated in a survey designed to study the intention to migrate to foreign countries:

1. How does the Government of Kazakhstan regulate the distribution of highly-qualified specialists across the country's regions?

2. What factors influence the migratory mood of Bolashak international scholarship holders?

\section{Data and methods of research}

The study uses a multi-method research design to ensure the rigor and reliability of the data and results to be presented. To measure the effectiveness of the Government policy regulating and balancing the number of highly-skilled specialists working across Kazakhstan's regions, the legislative base of the Bolashak program and the statistical data on the employment of the scholarship alumni have been analyzed. Special attention was given to how the Government manages the employment issues of Bolashak graduates and distributes them across the country.

At the same time, 724 students and graduates of the Bolashak program were surveyed to identify socio-economic factors affecting their decision to leave abroad. The respondents represent the age categories from 24 to 45. The study was conducted using the online tool Survey Monkey. The main goal of the survey was to reveal migration plans and attitudes, as well as to understand the respondents' social and economic characteristics and how they correlate with migration sentiments.

On the basis of the results of the survey, a portrait of a typical representative of the sample was drawn up. $48 \%$ of the students and graduates of the Bolashak program are aged 29 to 35, with over $30 \%$ of those surveyed between 23 to 28 years old and $11 \%$ over 36 years old. There was no gender imbalance.

Most Bolashak students graduated from schools in Nur-Sultan, Almaty and Karaganda region. Socio-economically, $67 \%$ of students identified their family's level of income as average, with an additional $18 \%$ identifying it as above average. Over $11 \%$ identified the level of prosperity as below average. More than $32 \%$ of the respondents interviewed received their Bachelor's degree in Almaty, $19 \%$ outside of Kazakhstan and $15 \%$ in Nur-Sultan. Over half of the respondents are students of the latest graduate study programmes of foreign universities counted among the TOP 100 best universities in the world. 


\section{Historical background of the Bolashak program}

The economic crisis and transformational changes caused by the transition to a market economy in Kazakhstan after gaining independence in 1991 and the necessity to build a sovereign nation in a globalized world required a significant modernization of the social and economic sectors. The Bolashak International Scholarship Program, created in 1993 by the Decree of Nursultan Nazarbayev, the President of the Republic of Kazakhstan, was meant to generate a comprehensive vision and expertise.

From its foundation in 1993 and during the 25 years of its existence, the development of the Bolashak International Scholarship Program has been gradual and characterized by multiple amendments, each of which aimed at strengthening not only the fit of the program to the goals of national strategic development, but also the rigor in scholar selection and quality requirements for eligible higher education institutions abroad.

During the first ten years following its formation, the Bolashak International Scholarship Program was focused on supporting the accumulation of contemporary knowledge needed for Kazakhstan to modernize its economy and public administration. From 1993 to 1997, scholarships were awarded for studies in social sciences, including the discipline of economics. During this time, the program became institutionalized as part of Kazakhstan's education policy with rigorous scholarship award procedures introduced in 1997. From 1997 onwards, scholarship applicants have been required to demonstrate superior academic achievement, Kazakh and foreign language proficiency and psychological well-being. Work placement procedures in public administration and other organizations for Bolashak alumni were also advanced. The scholarship was awarded for studies in master's degree programs at higher education institutions in France, Germany, Great Britain and the United States of America (CIP, 2018).

In 2000, the program was additionally revised to strengthen its alignment with the goals of Kazakhstan's industrial and innovation strategy. These adjustments allowed a better balance between scholarship recipients with degrees in social sciences and those with degrees in engineering and technical sciences. At that point foreign language skills often placed applicants within social sciences in a more advantageous position. In 2000, foreign language requirements were adjusted to encourage scholarship allocations to STEM, where applicants might have a lower foreign language proficiency (CIP, 2018). In 2004, the Bolashak scholarship began supporting doctoral candidates.

In 2005, the number of Bolashak scholarships increased to up to 3000 scholarships per year, including scholarship allocations for bachelor's degree programs abroad. JSC Center for International Programs (hereafter - CIP) became the responsible institution in organizing the admission and selection of Bolashak students and monitoring their study progress, return and employment upon graduation (CIP, 2018). Bolashak's expansion was accompanied by a diversification of allowed disciplines comprising education, management, logistics and information technologies. A mechanism to secure the return of Bolashak alumni was also introduced. Bolashak applicants were obliged to provide collateral in the form of real estate equivalent to the value of the scholarship, as determined by the program length, fees and the minimum standard of living in the country of study. If the value of the property is insufficient, up to four co-signatories can be used (CIP, 2018). For example, a master's degree at an American university typically requires two years of full-time study, while in England it takes approximately one year. In Russia, even though the duration of studies in a master's program is also typically two years, the tuition is relatively small compared to Western and European universities. Graduates who do not come back must return all expenses spent on their studies as well as a penalty that amounts to $10 \%$ of total expenses.

Between 2008 and 2010, new scholarship quotas for non-degree studies or internships and selected categories for applicants (e.g. rural origin, civil servants or research/teaching backgrounds) were announced to support the modernization of specific sectors of the economy (Government Decree, 2008). However, the program stopped awarding new scholarships for undergraduate studies. The opening of Nazarbayev University in Nur-Sultan in 2010 assumed the role of providing internationally competitive undergraduate education to students in Kazakhstan. 
In 2011, a targeted approach to fund the foreign education of specialists based on specific requests from employers was introduced. The distribution of such scholarships is based on a trilateral agreement between the scholarship recipient, their employer and JSC Center of International Programs. This approach has stimulated the expansion of internship programs in medicine, law, finance, cybersecurity, research and professionals in STEM employed in public and private sector organizations (CIP, 2018).

Recent amendments to the Bolashak International Scholarship program have been focused on increasing the quality of scholarship candidates, recipients and eligible universities. The minimum GPA has been increased to 3.0 - 3.3 out of 4 points. A sophisticated test assessing candidates' social and other competencies, motivational essays and recommendation letters were introduced (Government Decree, 2017). The minimum level of English language proficiency stands at IELTS 5.0 - 5.5. In two stages (half a year in Kazakhstan and half a year abroad), foreign language courses are offered.

Study destinations for Bolashak students are based on global university rankings, i.e. Times Higher Education, QS World University Ranking and Academic Ranking of World Universities. Since 2017, the Bolashak International Scholarship has been awarded to candidates admitted to universities ranked in the top 70 overall globally and the top 20 in the applicants' field of study (CIP, 2018).

Throughout 25 years of its existence, the Bolashak International Scholarship Program has served as a model to develop similar programs for countries, such as Russia, Poland, Ukraine, Malaysia and China. The unique characteristic of the Bolashak scholarship is its full coverage of all fees and expenses.

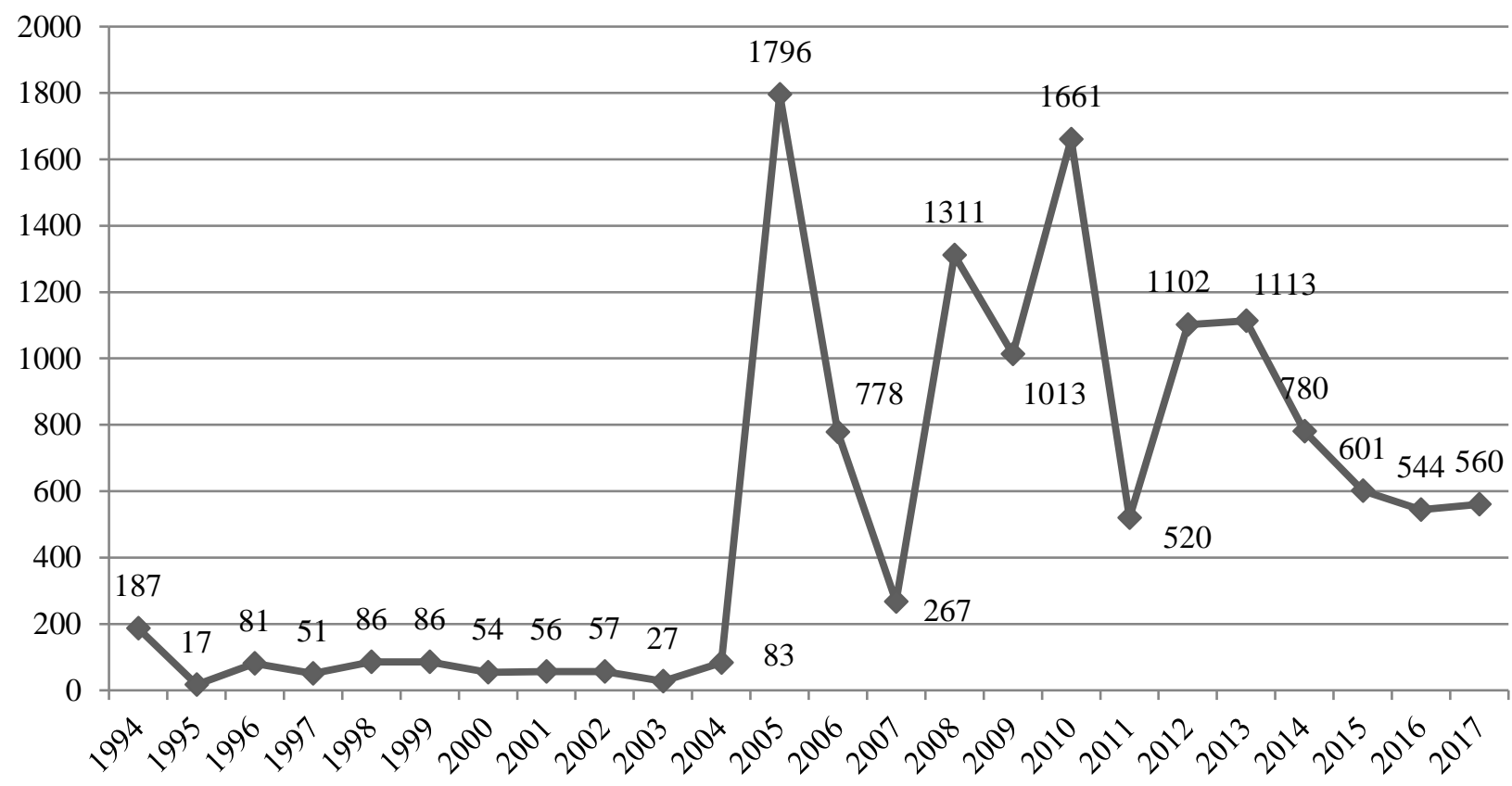

Fig. 1. The number of the Bolashak scholarships awarded per year

Source: CIP, 2018.

Note: A sharp decrease in the number of scholarships in 2007 may be due to the introduction of new regulations for awarding scholarships.

By 2018, more than 13,000 Bolashak scholarships had been awarded and over 10,000 specialists had been trained at the top universities in the world. Approximately $53 \%$ of the Bolashak graduates completed training in the humanities, $38 \%$ in STEM, $7.3 \%$ in medical fields, and $1.7 \%$ in art-related fields. $44 \%$ of the graduates completed their studies in the UK and Ireland, $26 \%$ in the 
USA and Canada, $14 \%$ in Asia and Oceania, $8 \%$ in continental Europe, and $8 \%$ in Russia (CIP, 2018).

\section{Government regulations for utilizing the high skills of Bolashak graduates}

This study on government regulation of intellectual migration in Kazakhstan in the frame of the Bolashak program acknowledges that studies abroad influence students' further career development and choices. Studies abroad assist in clarifying career plans and contribute to igniting an interest in a career direction as well as constituting potential ethical issues (Dwyer, 2004; Hadis, 2005). The experience of studying abroad may also constitute a valuable opportunity for participants to achieve a better understanding of themselves and to develop responsible leadership competencies. This perspective, in turn, creates a more ethical leader-stakeholder relationship, in which leaders serve as "facilitators of relational processes of co-creation and orchestrators for achieving common goals" (Maak and Pless, 2006).

After the successful completion (required) of their studies abroad, Bolashak scholarship holders must return to Kazakhstan and carry out compulsory labour activities (work obligations), the duration of which depends on the program of study (CIP, 2018). If necessary, CIP provides assistance in finding employment. Until 2017, the mandatory working period for academic programs (doctoral, master's, bachelor's) was five years and three years for scientific and professional internship programs. Singapore, Malaysia, France, the US and Russia apply scholarship requirements analogously; however, the length of service may vary.

The Kazakh Government regularly reassesses the mandatory working obligation terms of Bolashak graduates to increase investment payback and to widen the geographical distribution of its graduates. This policy is meant to foster regional development and appeal to a high-skilled workforce. Thus, in 2017, obligatory labour commitments for those who work in the countryside were reduced to up to 3 years, while those who work in major cities are kept at 5 years (Government of RK dated 05.19.2017 No. 279). Furthermore, from 2018 onwards, graduates have engaged in labour activities at regional educational organizations (in small cities, districts, counties, etc.) and had their term of work obligation decreased to up to 2 years (Resolution of the Government of the Republic of Kazakhstan dated March 27, 2018 No. 143). These changes have only recently started to have an effect, increasing the percentage of those working outside the major cities of Almaty and Nur-Sultan $3-5 \%$ to the current amount of about $30 \%$ of the total (CIP, 2018).

\section{Intellectual migration of Bolashak program alumni}

Intellectual migration is defined as the movement of qualified specialists for intellectual and professional activities (Fermi, 1986; Jay, 1944; lo Strote, 2015). This type of migration also promotes social, cultural and spiritual interchange between newcomers and the local population. Only regions with high rates of economic development and a high standard of living can attract most skilled professionals (Nteziryayo \& Hawkins, 1982; Costa, Cooper, Shierholz, 2014). Almaty (the former capital city) and the capital city of Nur-Sultan concentrate 4,348 and 3,128 graduates, or $44.1 \%$ and $31.7 \%$, respectively out of the total of 9,852 graduates (CIP, 2018).

Out of 9,852 Bolashak graduates who had earned their academic degree and internship certificates, 4,899 graduates completed their work obligation by 2019 and 4,741 have been working towards fulfilling their work commitments. A number of graduates have had their work requirement deferred due to further training or studies, childcare, etc. (CIP, 2019).

Today, about half $(46.5 \%)$ of Bolashak graduates work in the quasi-public sector, one third $(32.3 \%)$ in Kazakhstani private companies, $12 \%$ in state bodies, $7.3 \%$ in foreign companies, $1 \%$ in diplomatic and international organizations, and $0.9 \%$ in public associations. The employment rate among graduates is $98-99 \%$. Most graduates work in education and science $(27 \%)$, the finance and economic sector $(20.3 \%)$, the public administration sector $(15.8 \%)$, the IT and industrial sector 
(about $14.7 \%$ ), oil and gas engineering (9.8\%), the medical sector $(6 \%)$ and in other sectors of the economy (CIP, 2018).

It is plausible that the country's fast-developing and industrial regions, buoyed by oil and gas industries, have become desirable for Bolashak graduates. For example, the Atyrau region holds 594 Bolashak graduates, while the Turkestan region has 270 graduates, East Kazakhstan region 208 graduates and Karaganda 182 graduates. However, regions with limited industrial-innovative sites, scarce job opportunities and severe weather conditions host the fewest numbers of Bolashak graduates. Only 43 graduates live and work in Kostanay, while 58, 76 and 79 graduates live and work in North-Kazakhstan, Kyzylorda and Zhambyl respectively.

According to experts, such a tendency can also be explained by the number of candidates who participate in the competition for the Bolashak scholarship (Figure 2). Candidates from deprived regions of Kazakhstan are in most cases unable to provide immovable property equivalent to the value of the Bolashak scholarship and pursue other options instead. For example, young people from northern Kazakhstan may study at Russian universities for free, as provided by the Russian Federation to citizens from former Soviet Union (Agreement on granting equal rights to citizens of the Commonwealth of Independent countries to enter educational institutions, 1998, 24 November). According to the available data, around 100,000 Kazakh youth study in Russia (Sputnik, 2019).

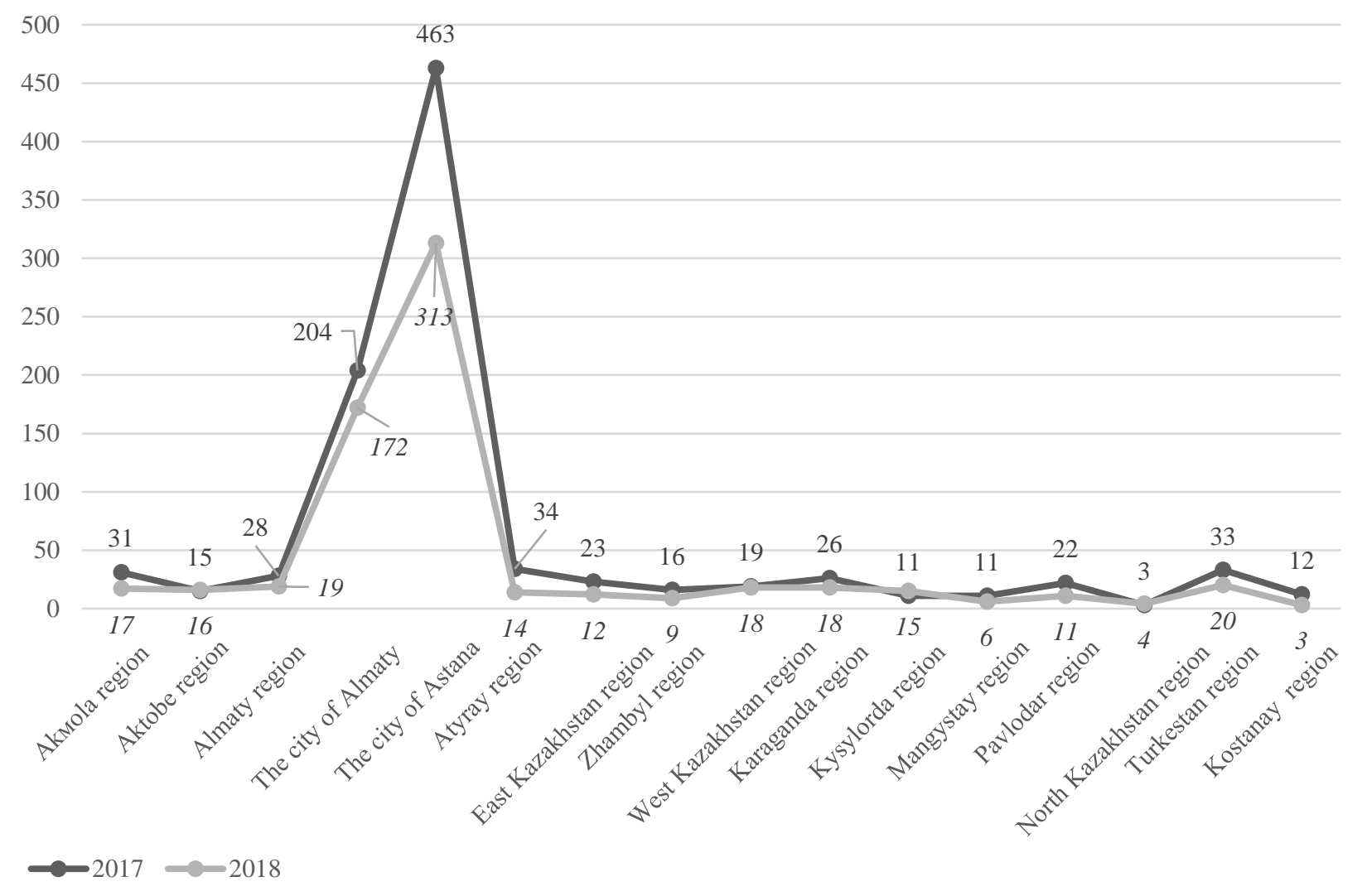

Fig. 2. The distribution of applicants for the Bolashak scholarships by region of residence, 2017-2018

Source: CIP, 2018.

Note: the city of Astana has been renamed to Nur-Sultan.

The most significant numbers of Bolashak alumni work in state and local administrations, economy and finance, STEM, medicine and education. As mentioned earlier, the highest numbers of alumni are in the capital, Nur-Sultan. The special economic zone Astana is also there, representing a massive infusion of local and foreign investments. As a result, Nur-Sultan employs 973 managers of various levels, 832 economists and financiers, 630 STEM workers, 470 teachers and 327 medics (CIP, 2018). Representatives of areas such as ecology (55 people), agriculture (28 people) and marine 
technology and navigation (5 people) comprise an insignificant share among Bolashak-eligible fields. The second major city of the country, Almaty, also employs the most significant number of economists and financiers (845 people), STEM personnel (588 people), public administration employees (399 persons), educational workers (344 people) and workers in medicine (192 people) (CIP, 2018).

Significant concentration of labour resources can also be linked to the investment volume made by regions for the development of a particular sector of the economy. For example, in NurSultan (the capital city), in 2017, spending on education and medicine amounted to $20.2 \%$ and $9 \%$ respectively of the city's total budget. According to the available data, the Government of Almaty city also pays extraordinary attention to the development of education: in $2017,54 \%$ of the city's total budget was dedicated to education, while $10 \%$ was allocated to medicine. Meanwhile, in NorthKazakhstan region, the expenditures for these areas amount to only $6.2 \%$ and $8.2 \%$ respectively, in Kostanay region $10.3 \%$ and $11 \%$ and in Zhambyl region $10.3 \%$ and $11.5 \%$ (Table 1).

The reduction in the obligatory work term for Bolashak graduates might be a strategic decision to motivate highly-skilled employees to relocate outside of major cities. Even though the government is taking active measures to develop and modernize the regions through the creation of various industrial enterprises and economic zones, the standard of living, average salary, and infrastructural characteristics remain unattractive for most highly-skilled professionals. According to the Statistics Committee of the Ministry of National Economy of Kazakhstan, in the third quarter of 2018 the highest wages are paid in the Atyrau region (310,568 tenge), in Mangystau (273,160 tenge), in Nur-Sultan (240,683 tenge). In Almaty city, the average wage was 197,736 tenge, 155,796 tenge in West Kazakhstan, 146,324 tenge in Karaganda, 137,526 tenge in Aktobe, 135,841 tenge in East Kazakhstan, 132,829 tenge in Kyzylorda, 21,358 tenge in Akmola, 113,716 tenge in Shymkent, 113,660 tenge in the Almaty region, 110,988 tenge in Zhambyl, 110,853 tenge in North Kazakhstan; and 98,834 tenge in the Turkestan region (ML, 2018). Therefore, local governments should work on attractting Bolashak graduates who can bring advanced technologies, valuable international experience and networks to their communities and workplaces.

Table 1. Information on the budgets of individual regions of Kazakhstan for 2017-2018

\begin{tabular}{|l|l|l|l|l|l|l|}
\hline REGIONS & \multicolumn{3}{|c|}{2017} & \multicolumn{4}{|c|}{2018} \\
\cline { 2 - 7 } & $\begin{array}{l}\text { Education } \\
\text { (thousands } \\
\text { tenge) }\end{array}$ & $\begin{array}{l}\text { Medicine } \\
\text { thousands } \\
\text { tenge) }\end{array}$ & $\begin{array}{l}\text { Total expenses } \\
\text { thousands } \\
\text { tenge) }\end{array}$ & $\begin{array}{l}\text { Education } \\
\text { (thousands } \\
\text { tenge) }\end{array}$ & $\begin{array}{l}\text { Medicine } \\
\text { (thousands } \\
\text { tenge) }\end{array}$ & $\begin{array}{l}\text { Total expenses } \\
\text { thousands } \\
\text { tenge) }\end{array}$ \\
\hline Nur-Sultan & 63914373 & 27796999 & 414273981 & 54882815 & 7456640 & 236005818 \\
\hline Almaty & 54299428 & 23681639 & 237234994 & 57855474 & 2196197 & 263744263 \\
\hline $\begin{array}{l}\text { North } \\
\text { Kazakhstan }\end{array}$ & 9342370 & 12269326 & 150221143 & 8192517 & 2337504 & 110469087 \\
\hline Kostanay & 14788655 & 17981778 & 163471433 & 16836408 & 3228997 & 132414533 \\
\hline Kyzylorda & 22459982 & 24592227 & 176015920 & 18663779 & 5559702 & 147521774 \\
\hline Zhambyl & 21781554 & 24369330 & 211042354 & 21080385 & 7787203 & 189707077 \\
\hline Turkestan & 61409788 & 54214261 & 497448039 & 47602570 & 15613863 & 436941171 \\
\hline
\end{tabular}

Source: Data from local municipalities.

\section{What influences Bolashak graduates' decision to work in Kazakhstan or overseas?}

According to the survey results, the most popular fields among the respondents were technical, economic and public administration. Among them, $49 \%$ of respondents have indicated a desire to be competitive in the labour market, while $30 \%$ wish to contribute to the country's development. In addition, Bolashak graduates hold additional preferences regarding the organizational structure of favoured workplaces; $30 \%$ of them seek a job in private companies, $27 \%$ in international organizations, $23 \%$ in public services and about $21 \%$ want to engage in academic activities/teaching. 
Salary expectations were quite high among respondents. More than half of Bolashak graduates indicated that they anticipated a monthly income ranging from 500 to 20,000 US Dollars. About $40 \%$ of the respondents estimated their chances of finding suitable employment as uncertain while more than $36 \%$ were confident in their skills and employment opportunities in Kazakhstan.

The study could not detect noticeable migratory moods among respondents; half of the surveyed Bolashak graduates do not plan to leave Kazakhstan for permanent residence in other parts of the world; specifically, these respondents put family values and patriotic commitments before their personal desires.

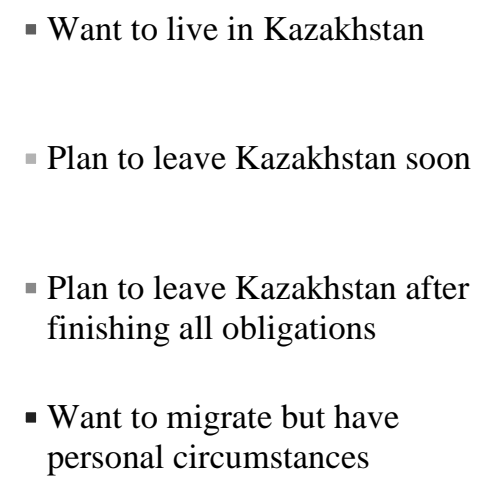

Fig. 3. The migratory intentions of respondents

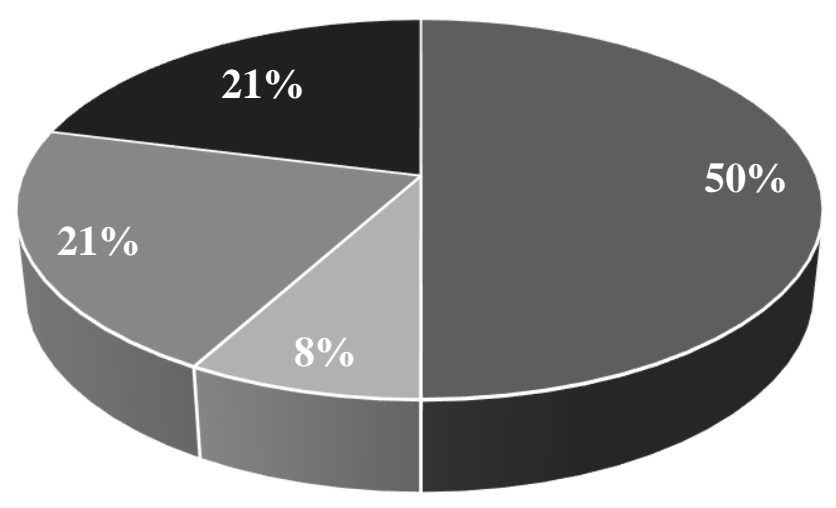

Source: Authors.

As can be seen from the chart, a substantial number of the respondents still want to migrate to other countries; $21 \%$ cannot migrate due to serious personal circumstances; and about $29 \%$ of respondents are planning to relocate after a while, including the individuals who would like to complete their obligations and move abroad (Figure 3). Motives for migration include a higher standard of living and promoting business.

The regression analyses have revealed that those aged 23 to 28 are mainly interested in "the standard of living of the country of destination", and less interested in "career opportunities", whereas Bolashak graduates between 29 to 35 years old and older are interested in "career opportunities" and less in the "standard of living". A recent study held by BRIF Research Group among young people in Kazakhstan between 14 and 40 years old (627 participants) has also revealed that young people between 23 to 28 years old are mainly interested in traveling, while those aged 36 and older are in favour of better living conditions for their families (Walter and Kazakov, 2018). Study participants between 29 to 35 years old are particularly interested in career prospects. These findings imply that the Kazakh Government should create better career opportunities in the country to prevent brain drain.

Interestingly, Bolashak graduates with higher incomes are not interested in career prospects in other countries, while those with average incomes prefer to improve their financial situation abroad. Notably, Bolashak graduates with low wages are not interested in career prospects and they seem uncertain about their capabilities. Furthermore, the study illustrates that Bolashak graduates between 23 and 28 years old return to Kazakhstan mainly due to their obligations to the Government. Those aged 29 and older are more likely to return as a result to patriotic considerations and family roots. This finding might imply that more careful attention should be paid to patriotic education and family values among young people. 


\section{Conclusions}

The Government of Kazakhstan took decisive measures to develop the country's human capital through the training of highly-qualified personnel in the world's best universities. Overall, Bolashak has seen 10 thousand highly-qualified specialists trained.

The Government of Kazakhstan has adopted an active policy of agreeing on an immovable property collateral, the value of which is equivalent to the costs of studies abroad (considering the duration of studies, tuition fees and other expenses). This mechanism served as a reliable guarantor for the return of graduates. Another significant governmental approach towards regulating the flow of highly-qualified specialists is decreasing the terms of work obligations. In order to simulate the rotation of highly-skilled specialists across the country's regions, the working term at the regional level was reduced from 5 years to 3 years, even though the working term for graduates in large cities, such as Nur-Sultan and Almaty, remains five years.

Importantly, a certain migratory mood has been detected. Many graduates aged 23 - 28 years still intend to leave the country after completing their compulsory work obligations. An important factor influencing the decision to leave is macroeconomic, i.e. wages and the standard of living are a considerable reason to migrate abroad. On the other hand, strong connections to the family and traditions are key factors that influence most graduates' decision to stay in Kazakhstan. Finally, the confidence that holders of foreign academic degrees will ultimately secure jobs in Kazakhstan, social awareness and reunifying with friends are other significant reasons keeping Bolashak graduates at home.

\section{References}

1. Committee of Statistics. The brain drain is growing - technicians, economists, and teachers are actively leaving Kazakhstan. http://finprom.kz/ru/article/utechka-mozgov-narastaetkazahstan-aktivno-pokidayut-tehnari-ekonomisty-pedagogi-ottok-kvalificirovannyh-kadrovza-poslednie-4-goda-uskorilsya-na-34-88 [2019-12-11]

2. CIP. About a quarter of Bolashak residents are top managers of large companies and state organizations. https://www.bolashak.gov.kz/ru/o-kompanii/smi-o-nas.html [2018-05-11]

3. Costa, D., Cooper, D., and Shierholz, H. Facts about Immigration and the U.S. Economy. Economic Policy Institute. August 2014. pp.1-14

4. Decree of the President of the Republic of Kazakhstan. On the establishment of international scholarships of the President of the Republic of Kazakhstan "Bolashak" for training personnel abroad, 1993 November 5, No. 1394

5. Dwyer, M. Charting the impact of studying abroad. International Educator. 2004. 13, pp.1417.

6. Hadis, B. Why Are They Better Students when They Come Back? Determinants of Academic Focusing Gains in the Study Abroad Experience. Frontiers: The Interdisciplinary Journal of Study Abroad. 2005. 11, pp.57-70

7. Fermi L. Illustrious immigrants; the intellectual migration from Europe, 1930-41. University of Chicago Press, 1968. p.440

8. Jay M. Permanent essays exiles on the intellectual migration from Germany to America. Columbia University Press. June 1990. p.328.

9. Strote, N. The intellectual migration and the other Weimar. Cambridge University Press: September 2015. Vol.14, No 2., pp. 597-606

10. The average monthly nominal wage per employee in Q3 2018 was 161,783 tenge. https://www.enbek.gov.kz/en/node/357894 [2018-11-11]

11. Today, about three thousand Kazakhstani applicants have applied for free education in Russian universities. kz.cdn.ampproject.org/v/s/ru.sputniknews.kz/amp/education/20190212 19263620/russia-vuz-granty-kazakhstan [2019-02-12]

12. Maak, T. and Pless, N. Responsible Leadership in a Stakeholder Society - A Relational Perspective. Journal of Business Ethics. 2006. 66: 99-115 
13. Nteziryayo, A., and Hawkins, J. International migration of talent: Africans in Southern California. University of California, Los Angeles-Education.1982.

14. Walter, P., and Kazakov, D. Five interesting facts about Kazakhstani youth. Kapital. August 2018.

Baurzhan Bokayev, Zulfiya Torebekova, Zhuldyz Davletbayeva

\section{Protų nutekẻjimo valdymas Kazachstane, igyvendinant vyriausybės politiką ir suteikiant „Bolašak" stipendijas}

Anotacija

Šiame straipsnyje aptariamas Kazachstano Respublikos vidinę intelektualinę migraciją pagal Prezidento stipendijų programą „Bolašak“, kuria siekiama paruošti aukštos kvalifikacijos specialistus geriausiuose pasaulio universitetuose. Analizė apima valstybės investicijų i aukštos kvalifikacijos specialistų rengimą mechanizmus, reguliavimo priemones, skatinančias ịsidarbinimo galimybes regioniniu lygiu, ir „Bolašak“ absolventų vidinès intelektualinès migracijos geografinę apimtị. Remiantis „Bolašak“ absolventų apklausa, ịvertintos šalies darbo rinkos galimybès ir nustatyti veiksniai, turintys įtakos Kazachstano jaunimo migracijai.

Tyrimo rezultatai parodè, kad dauguma „Bolašak“ programos absolventų nori prisidèti prie šalies vystymosi, tačiau jų netenkina atlyginimų lygis Kazachstane. Migracijos nuotaikos buvo pastebimos tarp 23-28 metų absolventų, tačiau vyresni, 29-35 metų, absolventai mieliau likdavo savo šalyje. Be to, pirmoje absolventų grupeje prioritetas buvo teikiamas gyvenimo lygiui šalyje, i kurią ketina migruoti, o ne profesinèms galimybėms. Antrosios grupès absolventai labiau domèjosi karjeros galimybėmis, o ne gyvenimo lygiu šalyje, ị kurią ketina migruoti.

Straipsnis parengtas naudojantis finansine Kazachstano Respublikos švietimo ir mokslo ministerijos parama 2018-2020 m. igyvendinant projektą Nr. AP05136246 „Kazachstano Respublikos migracijos politikos modernizavimas šalies intelektualinio potencialo plètros kontekste”.

Baurzhan Bokayev - PhD, Professor of National School of Public Policy of the Academy of Public Administration under the President of the Republic of Kazakhstan

E-mail: bbokayev@syr.edu; b.bokayev@apa.kz

Zulfiya Torebekova - PhD student at Maxwell School of Citizenship and Public Affairs, Syracuse University, USA

E-mail: tzulfiya@syr.edu

Zhuldyz Davletbayeva - PhD, Professor of National School of Public Policy of the Academy of Public Administration under the President of the Republic of Kazakhstan

E-mail: zhuldyz.davletbayeva@apa.kz

Baurzhan Bokayev - mokslų daktaras, Viešojo administravimo akademijos prie Kazachstano Respublikos prezidento Nacionalinės viešosios politikos mokyklos profesorius

E1. paštas: bbokayev@syr.edu; $\underline{\text { b.bokayev@apa.kz }}$ 
Zulfiya Torebekova - doktorantė Maxwell Pilietybės ir viešųjų reikalų mokykloje, Sirakūzų universitete, JAV

El. paštas: tzulfiya@syr.edu

Zhuldyz Davletbayeva - mokslų daktaré, Viešojo administravimo akademijos prie Kazachstano Respublikos prezidento Nacionalinès viešosios politikos mokyklos profesorè

El. paštas: zhuldyz.davletbayeva@apa.kz 